\title{
炭素蒸着窒化ケイ素粉末から作製した $\mathrm{Si}_{3} \mathrm{~N}_{4} / \mathrm{SiC}$ ナノ複合体の 高温での機械的強度
}

\author{
柳井知宏 $* * *$ ・濱崎豊弘 $*$ 石㠃幸三* \\ *長岡技術科学大学機械系材料設計大講座, 940-21 新潟県長岡市上富岡町 1603-1 \\ **防衛庁技術研究本部第 1 研究所, 153 東京都目黒区中目黒 2-2-1
}

\section{High Temperature Mechanical Strength of $\mathrm{Si}_{3} \mathrm{~N}_{4} / \mathrm{SiC}$ Nanocomposite Prepared from Carbon Coated $\mathrm{Si}_{3} \mathrm{~N}_{4}$ Powder}

\author{
Tomohiro YANAI***, Toyohiro HAMASAKI* and Kozo ISHIZAKI* \\ *Department of Material Science and Engineering, Nagaoka Gijutsu-Kagaku Daigaku (Nagaoka University of Technology), \\ 1603-1, Kamitomioka-cho, Nagaoka-shi, Niigata 940-21 \\ **1st Research Center, Technical Research \& Development Institute, Japan Defense Agency, 2-2-1, Nakameguro, Meguro-ku, Tokyo
}

[Received March 6, 1995; Accepted July 6, 1995]

Highly densified sintered $\mathrm{Si}_{3} \mathrm{~N}_{4}$ bodies are conventionally obtained through liquid phase sintering by adding sintering aids to overcome difficulty of sintering due to the strong covalent bonding in $\mathrm{Si}_{3} \mathrm{~N}_{4}$. Sintered $\mathrm{Si}_{3} \mathrm{~N}_{4}$ ceramics contain a weak grain boundary phase, which is produced from a reaction between the sintering aids and the raw $\mathrm{Si}_{3} \mathrm{~N}_{4}$ powder, especially oxide phase of surface contamination on the $\mathrm{Si}_{3} \mathrm{~N}_{4}$ powder. Therefore, the grain boundary phase influences mechanical properties of $\mathrm{Si}_{3} \mathrm{~N}_{4}$ ceramics. The present paper discusses a method to enhance mechanical properties by forming nano $\mathrm{SiC}$ particles in $\mathrm{Si}_{3} \mathrm{~N}_{4}$ system with additives, especially in grain boundary phase. The $\mathrm{Si}_{3} \mathrm{~N}_{4}$ ceramics with dispersed nano $\mathrm{SiC}$ particles were obtained by using a $\mathrm{Si}_{3} \mathrm{~N}_{4}$ powder coated by carbon, which was obtained by thermal decomposition of methane $\left(\mathrm{CH}_{4}\right)$ gas. The nano $\mathrm{SiC}$ particles were formed by in-situ reaction between the oxide phase on the surface of the $\mathrm{Si}_{3} \mathrm{~N}_{4}$ powder and the coated carbon. The sintered bodies were obtained by hot-pressing at $1800^{\circ} \mathrm{C}$ for $1 \mathrm{~h}$ in $\mathrm{N}_{2}$ atmosphere under $30 \mathrm{MPa}$ of applied pressure. Results of mechanical property measurements showed that the bending strength and fracture toughness increased about $20-25 \%$, and the high temperature mechanical strength was also improved by the carbon coating method. TEM observation showed that the precipitated $\mathrm{SiC}$ particles were dispersed in three different types of locations, i.e., in the grain boundary layer, at the $\mathrm{Si}_{3} \mathrm{~N}_{4}-\mathrm{Si}_{3} \mathrm{~N}_{4}$ interface penetrating the grain boundary layer and inside of the $\mathrm{Si}_{3} \mathrm{~N}_{4}$ grain. $\mathrm{SiC}$ particles dispersed at the $\mathrm{Si}_{3} \mathrm{~N}_{4}-\mathrm{Si}_{3} \mathrm{~N}_{4}$ interface block grain boundary sliding and slow crack growth at high temperatures. For carbon coated samples, the quantity of grain boundary phase was smaller than the non-coated samples as shown by cryogenic specific heat measurements. The quantity of grain boundary phase decreases, which leads the improvement of high temperature mechanical strength also. Therefore, the high temperature strength was improved by precipitated $\mathrm{SiC}$ particles dispersion and decreasing the quantity of grain boundary phase.

Key-words : High temperature mechanical strength, $\mathrm{Si}_{3} \mathrm{~N}_{4} /$ SiC nanocomposite, In-situ reaction, Cryogenic specific heat
1. 緒 言

窒化ケイ素セラミックス $\left(\mathrm{Si}_{3} \mathrm{~N}_{4}\right)$ は, 難焼結性のため 焼結助剂を用いて緻密体を得ている．このため $\mathrm{Si}_{3} \mathrm{~N}_{4}$ 焼結 体中の結晶粒界には焼結助剤を主成分とする粒界ガラス相 及び粒界結晶相からなる粒界相が存在する. 粒界ガラス相 は，高温雲囲気では軟化するため, 粒界すべりやスローク ラックグロウスを生じ，高温特性の低下の原因となってい る.

機械的特性の改善方法として $\mathrm{SiC}$ 粒子との複合化に関 する報告がされ 1$) \sim 5)$, 特に $\mathrm{SiC}$ 粒子をナノサイズで分散 させると室温や高温での機械的特性が著しく改善されるこ とが報告されている5 。本研究ではナノ $\mathrm{SiC}$ 粒子を分散さ せる方法として, 渡利らが報告した炭素と $\mathrm{Si}_{3} \mathrm{~N}_{4}$ 粉末表面 の酸化不純物相との in-situ 反応による $\mathrm{SiC}$ 生成反応を利 用した6). その結果, 室温での機械的特性は単味焼結体に 比べ約 $25 \%$ 程度向上することを報告した ${ }^{7)}$ 。この方法で は, 粒界ガラス相が $\mathrm{SiC}$ 粒子で強化されるとともに粒界 相量も in-situ 反応により減少すると考えられるので, 高 温特性の向上も期待できる.

高温での機械的特性を議論する場合，粒界相量及び粒界 相の質，すなわち，粒界ガラス相と粒界結晶相の割合と高 温強度の関係を知ることは重要である。しかし, 粒界相量 の評価は従来はエッチングにより腐食量を光学顕微鏡等で 観察して評価する金相学的な手法に頼っているため 2 次 元での情報しか得られず測定感度は低い。また，粒界ガラ ス相と粒界結晶相を区別できないので高い精度で粒界相量 を評価することは不可能である，一方，濱崎らは，粒界相 量をガラスが極低温下で異常比熱を示すことを利用して, 比熱測定から $\mathrm{Si}_{3} \mathrm{~N}_{4}$ セラミックス中の $\mathrm{Si}_{3} \mathrm{~N}_{4}$ 結晶と粒界ガ ラス相を定量化することに成功した ${ }^{8)}$ 。この方法では $\mathrm{Si}_{3} \mathrm{~N}_{4}$ 格子のデバイ温度が $\left.1100 \mathrm{~K}^{9}\right)$ に対して粒界結晶相の デバイ温度が $350 \mathrm{~K}^{8)}$ と差が大きいため, 粒界相中の粒界 ガラス相のみならず粒界結晶相の定量化も可能である.

本報告では，炭素蒸着 $\mathrm{Si}_{3} \mathrm{~N}_{4}$ 粉末から作製した $\mathrm{Si}_{3} \mathrm{~N}_{4} /$ $\mathrm{SiC}$ ナノ複合体の微細組織を透過型電子顕微鏡 (TEM) 
観察するとともに，粒界相量を定量化し，高温強度との関 係について検討した.

\section{2. 実験方法}

\section{1 炭素蒸着 $\mathrm{Si}_{3} \mathrm{~N}_{4}$ 粉末の作製}

出発原料として，イミド熱分解法で製造された $\alpha-\mathrm{Si}_{3} \mathrm{~N}_{4}$ 粉末（宇部興産製，SN-E10グレード，平均粒径：0.3 $\mu \mathrm{m}$ ，比表面積 : 9 $13 \mathrm{~m}^{2} / \mathrm{g}$ ) を使用した. 粉末表面には 前報同様, メタン $\left(\mathrm{CH}_{4}\right)$ ガスの熱分解を利用して炭素蒸 着を行った7). 蒸着量は0.29 mass\%であり，この值は本 出発原料粉末を用いたときに破壊勒性及び曲げ強度が最大 值を示した条件である7).

\section{2 焼結体の作製}

炭素蒸着 $\mathrm{Si}_{3} \mathrm{~N}_{4}$ 粉に焼結助剂として $\alpha-\mathrm{Al}_{2} \mathrm{O}_{3}$ （住友化学 工業製, 平均粒径 : $0.4 \mu \mathrm{m}$ ) と $\mathrm{Y}_{2} \mathrm{O}_{3}$ （信越化学工業製, 平均粒径： $0.9 \mu \mathrm{m}$ ）を各 $3 \mathrm{~mol} \%$ ずつ加え，エタノールを 分散媒としてポリエチレンポット中で $\mathrm{Si}_{3} \mathrm{~N}_{4}$ ボールを用い て湿式ボールミルを $24 \mathrm{~h}$ 行った. 乾燥後, 乾式ボールミル を $12 \mathrm{~h}$ 行い粉砕. 整粒し, 原料粉末とした. 同様の混合条 件で比較用に未蒸着粉末も調製した。焼結は, ホットプレ 又焼結法により, 焼結温度 $1800^{\circ} \mathrm{C}$, 焼結時間 $60 \mathrm{~min}$, 圧 力 $30 \mathrm{MPa}$ ，窒素䨌囲気 $0.1 \mathrm{MPa}$ ，昇温速度 $25 \mathrm{~K} / \mathrm{min}$ の条 件で行った. 得られた直径 $50 \mathrm{~mm}$, 厚さ約 $5 \mathrm{~mm}$ の焼結 体加ら切断及び研削 ·研磨加工により $3 \mathrm{~mm} \times 4 \mathrm{~mm} \times 36$ $\mathrm{mm}$ の試験片を作製し，以下の特性評価に供した。

\section{3 焼結体の特性評価}

特性評価は，密度及び曲げ強度について行った．密度は トルエン中でアルキメデス法で測定した．曲げ強度はファ インセラミックスの曲げ強さ試験法（JIS R1601）に基づ き, スパン $30 \mathrm{~mm}$, クロスヘッドスピード $0.5 \mathrm{~mm} / \mathrm{min}$ の 条件で室温から $1500^{\circ} \mathrm{C}$ までの大気中で 3 点曲げにより測 定した。

粉末及び焼結体の構成相の同定は $\mathrm{X}$ 線回折法で行った. 焼結体中の粒界結晶相及び粒界アモルファスガラス相, 並 びに $\mathrm{SiC}$ 量の定量は，10～ $30 \mathrm{~K}$ での低温比熱の測定によ り行った。更に，焼結体の微細組織は TEM で観察した。 TEM 試料はイオンシンニング法により作製した。

\section{3. 結 果}

\section{1 高温特性}

本焼結条件で，理論密度まで緻密化した焼結体が得られ た．図 1 に高温強度の測定結果を示す，室温強度は，炭素 蒸着粉末では未蒸着粉末から得た焼結体の $990 \mathrm{MPa}$ に対 し1250 MPa を示した. 高温特性は未蒸着粉末から得た焼 結体では, $800^{\circ} \mathrm{C}$ あ゙はほぼ室温強度の $990 \mathrm{MPa}$ を保持し ているが，これ以上の温度では強度が低下する傾向を示し た。一方, 炭素蒸着粉末から得た焼結体では室温から $1200^{\circ} \mathrm{C}$ な゙ $1000 \mathrm{MPa}$ 以上を保持し，室温のみならず高 温での機械的特性向上に本方法が有効であることが認めら れた。

\section{2 微細組織}

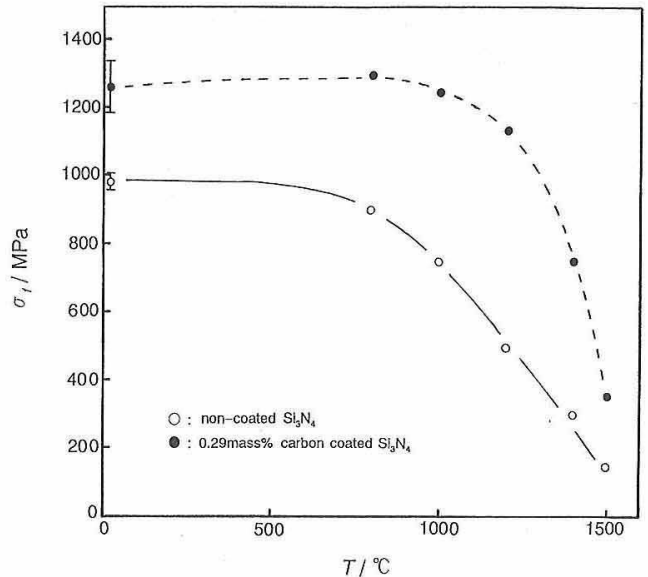

Fig. 1. Temperature, $T$, dependence of the bending strength, $\sigma_{f}$, for sintered $\mathrm{Si}_{3} \mathrm{~N}_{4}$ ceramics prepared from non-coated and 0.29 mass $\%$ carbon coated on the raw $\mathrm{Si}_{3} \mathrm{~N}_{4}$ powder.

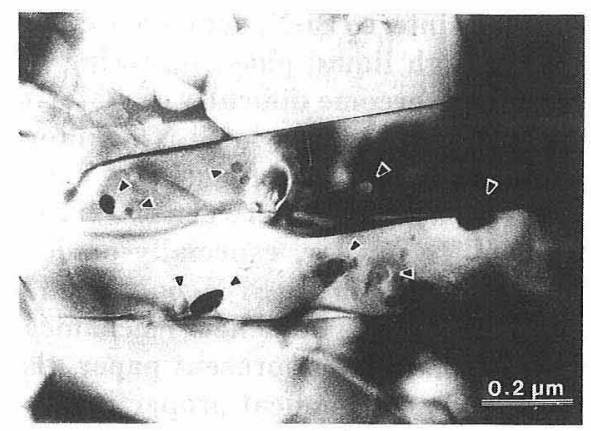

Fig. 2. Low magnification TEM micrograph of $\mathrm{Si}_{3} \mathrm{~N}_{4}$ ceramics prepared from 0.29 mass $\%$ carbon coated on the raw $\mathrm{Si}_{3} \mathrm{~N}_{4}$ powder. Arrows indicate precipitated nano size $\mathrm{SiC}$ particles.

$\mathrm{X}$ 線回折から，本系では焼結中の in-situ 反応により $\beta$ $\mathrm{SiC}$ 粒子が生成していることが確認された ${ }^{7)}$. 図 2 に0.29 mass\%炭素蒸着した原料粉末から作製した焼結体の $\mathrm{TEM}$ 像を示す. 生成した $\beta-\mathrm{SiC}$ 粒子は $\beta-\mathrm{Si}_{3} \mathrm{~N}_{4}$ の粒界力 ラス相及び粒内に分散している。

図 3 (a)に $\mathrm{Si}_{3} \mathrm{~N}_{4}-\mathrm{Si}_{3} \mathrm{~N}_{4}$ 界面の TEM 像を示す。この界 面は紙面に対して垂直であり，粒界ガラス相に相当するコ ントラストは約 $20 \mathrm{~nm}$ の厚さで広がっている. $\mathrm{Si}_{3} \mathrm{~N}_{4-}$ $\mathrm{Si}_{3} \mathrm{~N}_{4} 2$ 粒子界面の粒界相厚さは約 $1 \sim 2 \mathrm{~nm}$ との報告があ り10), 図3(a)の界面はイオンシンニング中に上方の $\mathrm{Si}_{3} \mathrm{~N}_{4}$ 粒子が脱落し, 三重点が露出した状態であると考え られる. 粒界相中に in-situ 反応で析出した SiC 粒子を確 認するために図 3 (a)の枠内部分を傾斜させ高分解能電子 顕微鏡（HREM）観察した結果が図 3 (b) である. 図中に 示すように $0.25 \mathrm{~nm}$ の面間隔を有する約 $5 \mathrm{~nm}$ の微結晶粒 子が認められ，この面間隔は $\beta$-SiC の (111) 面に相当す る. 従来報告されている $\mathrm{Si}_{3} \mathrm{~N}_{4} / \mathrm{SiC}$ 系では出発原料に粉末 を用いるため $\mathrm{SiC}$ 粒子径は数十 $\mathrm{nm}$ 程度までしか微細化 できなかったが，本系では in-situ 反応で $\mathrm{SiC}$ 粒子が生成 するため, $10 \mathrm{~nm}$ 以下の $\mathrm{SiC}$ 粒子を粒界ガラス相中に析 出・分散させることに成功した. したがって, 今まで報告 されているナノ複合材料の中で最も微細な第 2 相粒子が 


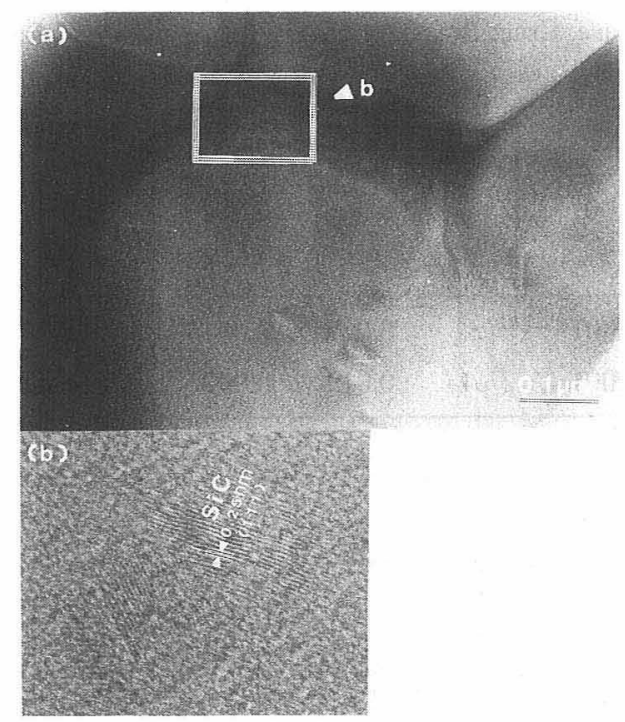

Fig. 3. (a) TEM and (b) HREM micrographs of nano SiC particles dispersed in grain boundary phase. The HREM image indicates enclosed region of (a). The lattice spacing corresponds with (111) plane of $\beta$-SiC.

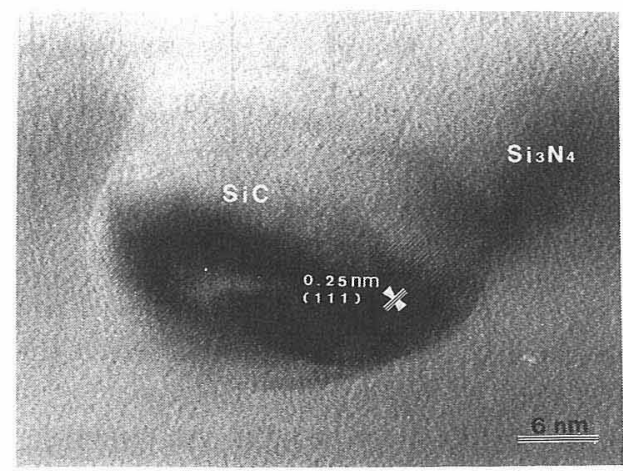

Fig. 4. HREM image of nano $\mathrm{SiC}$ particle dispersed at $\mathrm{Si}_{3} \mathrm{~N}_{4}$ grain inside. The lattice spacing of $\mathrm{SiC}$ particle corresponds with (111) plane of $\beta$-SiC.

\section{分散した組織を示している.}

図 4 には $\mathrm{Si}_{3} \mathrm{~N}_{4}$ 粒内に分散した $\mathrm{SiC}$ 粒子の HREM 像を 示す．析出した $\beta-\mathrm{SiC}$ 粒子と $\mathrm{Si}_{3} \mathrm{~N}_{4}$ の界面には異常なコン トラストは認められず，本方法により生成した $\mathrm{SiC}$ 粒子 近傍には反応相はないものと考えられる．生成した $\mathrm{SiC}$ 粒子は図 5 に示すように $\mathrm{Si}_{3} \mathrm{~N}_{4}-\mathrm{Si}_{3} \mathrm{~N}_{4} 2$ 粒子界面にも分散 し, $\mathrm{Si}_{3} \mathrm{~N}_{4}$ 粒子は他の隣り合った $\mathrm{Si}_{3} \mathrm{~N}_{4}$ 粒子と $\mathrm{SiC}$ 粒子を 介して結合している.

\section{3 低温比熱測定}

図 6 に低温比熱の測定結果を示す。図中の破線は $\mathrm{Si}_{3} \mathrm{~N}_{4}$ 格子のデバイ温度から比熱を計算した值を示す．焼結体の 低温比熱は両者とも計算值より高い比熱を示し，未蒸着粉 末から作製した焼結体の方がより高い低温比熱を示してい る.これは焼結体中には焼結助剤を主成分とする粒界ガラ ス相を有し，ガラスの低温での過剩比熱によるものと考え られる。また，粒界結晶相も似たような影響を与えてい る。粒界結晶相のデバイ温度は $350 \mathrm{~K}^{8)}$ と $\mathrm{Si}_{3} \mathrm{~N}_{4}$ の 1100 $\mathrm{K}^{9)}$ に比較して低いため低温での比熱が大きくなり計算值
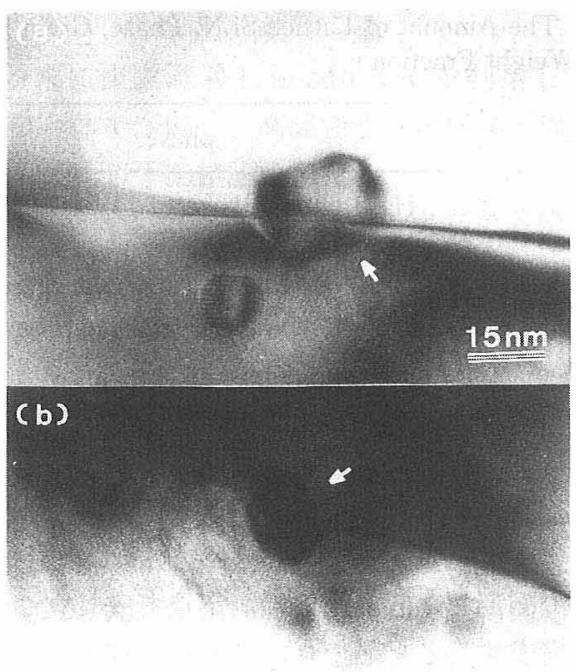

$15 \mathrm{~nm}$

Fig. 5. TEM micrographs of nano $\mathrm{SiC}$ particles dispersed at $\mathrm{Si}_{3} \mathrm{~N}_{4}-\mathrm{Si}_{3} \mathrm{~N}_{4}$ interfaces through the grain boundary phases.

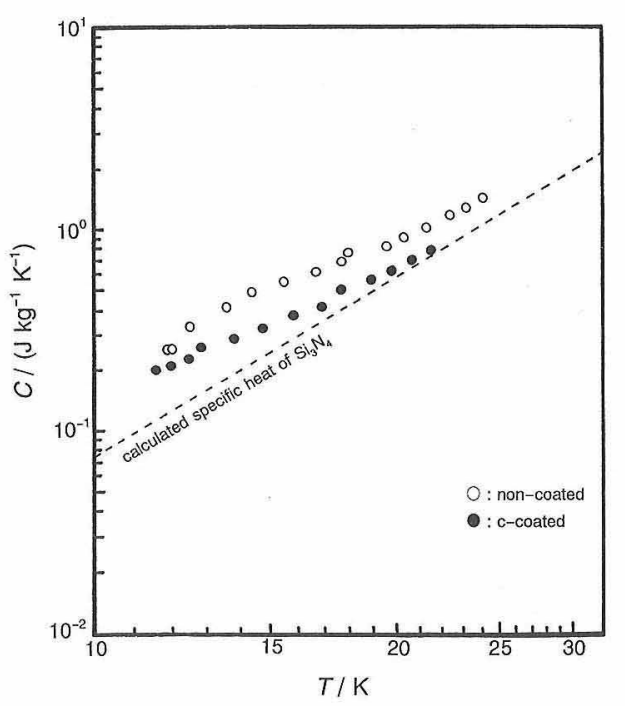

Fig. 6. Specific heat, $C$, as a function of temperature, $T$, for two types of $\mathrm{Si}_{3} \mathrm{~N}_{4}$ ceramics. Open and solid circles represent specific heat of the hot-pressed $\mathrm{Si}_{3} \mathrm{~N}_{4}$ prepared from as-received and 0.29 mass\% carbon coated on the raw $\mathrm{Si}_{3} \mathrm{~N}_{4}$ powders, respectively. The dashed line corresponds to calculated specific heat from Debye temperature, $1100 \mathrm{~K}$, of $\mathrm{Si}_{3} \mathrm{~N}_{4}$ lattice. ${ }^{6)}$

とずれを生じたものと考えられる。

\section{4. 考 察}

\section{1 焼結体の構成相の定量化}

図 6 に示した低温比熱測定結果から焼結体中の各相の 割合を定量する. 図 6 で得られた総比熱は(1)式で表すこ とができる8)。

$$
C_{\text {tot }}=x C_{\mathrm{G} . B . g l a}+y C_{\mathrm{G} . \mathrm{B} . \mathrm{cry}}+z C_{\mathrm{SN}}
$$

ここで, $C_{\mathrm{tot}}, C_{\mathrm{G} . \mathrm{B} . \mathrm{gla}}, C_{\mathrm{G} . \mathrm{B} . \mathrm{cry}}, C_{\mathrm{SN}}$ は各々焼結体の総比熱, 粒界ガラ久相の比熱, 粒界結晶相の比熱, $\mathrm{Si}_{3} \mathrm{~N}_{4}$ 相の比熱 
Table 1. The Amount of Lattice $\mathrm{Si}_{3} \mathrm{~N}_{4}$ Phase, Grain Boundary Crystalline Phase, Grain Boundary Glassy Phase and Precipitated SiC Phase in Weight Fraction

\begin{tabular}{lcc}
\hline \multicolumn{1}{c}{ phase } & non-coated & carbon coated \\
\hline Hard lattice phase of $D_{\theta}=1100 \mathrm{~K}$ & $\begin{array}{c}0.936 \pm 0.001 \\
\left(\mathrm{Si}_{3} \mathrm{~N}_{4}\right)\end{array}$ & $\begin{array}{c}0.956 \pm 0.002 \\
\left(\mathrm{Si}_{3} \mathrm{~N}_{4}+\mathrm{SiC}\right)\end{array}$ \\
\hline $\begin{array}{l}\text { grain boundary crystalline phase } \\
\text { grain boundary glassy phase }\end{array}$ & $0.010 \pm 0.001$ & $0.032 \pm 0.001$ \\
\hline
\end{tabular}

を表す。をた， $x, y, z$ は各相の割合を表す。（1)式は図 6 の各温度で測定した低温比熱の測定点で成り立つので連立 方程式を構成することができ，この式を解くことで各相の 割合を定量することができる. 実際の計算では $\mathrm{Si}_{3} \mathrm{~N}_{4}$ の格 子比熱はデバイ温度 $1100 \mathrm{~K}$ からデバイ理論により計算し た値を用い，粒界ガラス相及び結晶相の低温比熱は本粒界 相組成から作製した模擬粒界ガラス相及び結晶相の低温比 熱測定結果から得た比熱を用いた8).

表 1 と図 7 に本系の各相の定量結果を示す. 炭素蒸着粉 末から作製した焼結体中には in-situ 反応で生成した $\mathrm{SiC}$ 粒子を含んでいる. 低温比熱測定では $\mathrm{Si}_{3} \mathrm{~N}_{4}$ のデバイ温度 $1100 \mathrm{~K}$ に対し $\mathrm{SiC}$ は $1150 \mathrm{~K}$ とほほ等しいため両者を分 離することは困難であり, 定量したデバイ温度 $1100 \mathrm{~K}$ の 結晶相量中には生成した $\mathrm{SiC}$ 相も含まれている. $\mathrm{SiC}$ 相は 液相を形成する $\mathrm{Si}_{3} \mathrm{~N}_{4}$ 粉末表面の酸化不純物相と蒸着炭素 との in-situ 反応で生成するため炭素蒸着粉末を使用した 場合は，液相量は減少するとともに，この反応は $\mathrm{CO}$ ガス の放出を伴うので焼結後の総質量は出発原料粉末の総質量 より減少するはずである。一方, $\mathrm{Si}_{3} \mathrm{~N}_{4}$ 相の質量は炭素蒸 着の有無に関係なく不変であると仮定すれば， $\mathrm{Si}_{3} \mathrm{~N}_{4}$ 相量 は図 7 の未蒸着粉末から得た焼結体の定量結果加ら焼結 後の総質量の $93.6 \%$ である. 炭素蒸着粉末の焼結前後の炭 素量変化から放出した CO ガス量から総質量を計算し, 全 体の $93.6 \%$ が $\mathrm{Si}_{3} \mathrm{~N}_{4}$ 相量としてデバイ温度 $1100 \mathrm{~K}$ の結晶 格子量部分の残部が生成した $\mathrm{SiC}$ 量となる.

表 2 には表 1 と図 7 の低温比熱測定結果を基に計算し た $\mathrm{SiC}$ 相量と焼結前後の炭素量変化から計算した $\mathrm{SiC}$ 相 量の比較を示す．表から明らかなように低温比熱測定から 定量した值と計算値は良い一致を示しており，低温比熱測 定による $\mathrm{SiC}$ 相の定量結果は有効であることが分かった。

次に炭素蒸着粉末から得た焼結体中の粒界結晶相が増加 した原因について, 図 8 に示す $\mathrm{Al}_{2} \mathrm{O}_{3}-\mathrm{Y}_{2} \mathrm{O}_{3}-\mathrm{SiO}_{2}$ 三元系

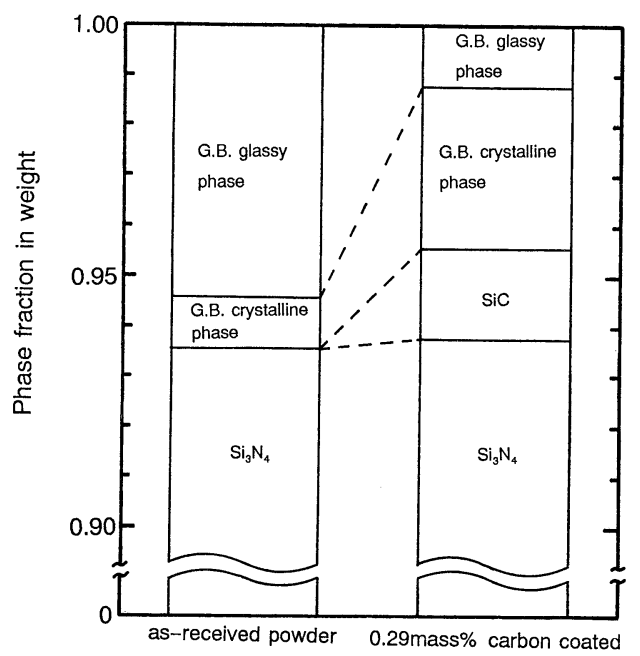

Fig. 7. The quantitative evaluation of two types of $\mathrm{Si}_{3} \mathrm{~N}_{4}$ ceramics.

の状態図から考察する．図中の破線で囲んだ領域はガラス 化領域を示し ${ }^{11)}$ ，図中の点は本系の出発原料の組成を示 す. $\mathrm{SiC}$ 相は焼結中の炭素々酸化ケイ素との in-situ 反応 で生成するため, 粒界相を構成する成分比が未蒸着粉末の 場合と異なる．そこで変化量について考光る．本系で用い た焼結助剤の $\mathrm{Al}_{2} \mathrm{O}_{3}$ と $\mathrm{Y}_{2} \mathrm{O}_{3}$ のモル比は $1: 1$ であるため 図 8 中の $\mathrm{AB}$ 線上で実験を行ったことになる，焼結中に in-situ 反応が生じると $\mathrm{SiO}_{2}$ 成分が減少するため粒界相成 分は $\mathrm{B}$ 点へ向かってシフトする. 更に, $\mathrm{Al}_{2} \mathrm{O}_{3}$ の一部は $\mathrm{Si}_{3} \mathrm{~N}_{4}$ 格子に固溶するため $\mathrm{AB}$ 線は $\mathrm{Y}_{2} \mathrm{O}_{3}$ リッチ側へシフ 卜する.したがって, 図 8 中に示した出発原料中の粒界 相成分は矢印の方向へシフトすることになり，ガラス化領 域外となり粒界相はガラスとして存在するよりも結晶相と して存在しやすくなり，図７に示した定量結果で粒界結 晶相の割合が増加したことが説明できる.

Table 2. Experimental and Calculated $\mathrm{SiC}$ Phase Fraction in Weight. Experimental SiC Phase Fraction is Evaluated by Cryogenic Specific Heat Measurements, as Shown in Fig. 7 and Table 1. Calculated SiC Phase Fraction is Estimated by Reacted Carbon Content, which is the Difference of the Carbon Content before and after Hot-Pressing

\begin{tabular}{cc}
\hline analytical method & SiC phase fraction \\
\hline evaluated by cryogenic specific heat measurements & 0.018 \\
estimated by reacted carbon content & 0.022 \\
\hline
\end{tabular}




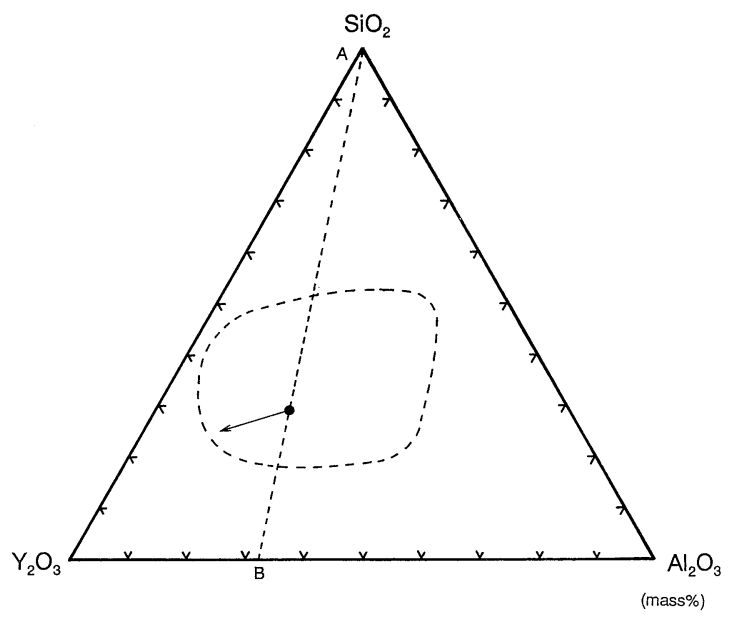

Fig. 8. $\mathrm{Al}_{2} \mathrm{O}_{3}-\mathrm{Y}_{2} \mathrm{O}_{3}-\mathrm{SiO}_{2}$ ternary phase diagram. The region enclosed by the dashed line indicates glass formation compositions as reported by Makishima et al. ${ }^{11)}$ at $1700^{\circ} \mathrm{C}$. $\mathrm{AB}$ line indicates experimental condition before sintering, i.e., the molar ratio of $\mathrm{Al}_{2} \mathrm{O}_{3}$ and $\mathrm{Y}_{2} \mathrm{O}_{3}$ is one. The arrow indicate the direction of the composition shift of grain boundary phase after sintering.

な押，X線回折からは粒界結晶相に起因するピークを バックグラウンドから分離し特定することができず，粒界 結晶相の存在及び同定はできなかった。しかし，濱崎らは 低温比熱測定によりX 線回折ではガラスと判断された酸 窒化ガラス中の結晶化率を定量できることを報告してい る12)。したがって，X線回折で確認されなかった粒界結 晶相量の炭素蒸着の有無による変化が低温比熱測定により 定量化できたものと考えられる，ただし，粒界結晶相の同 定については今後の検討課題である.

\section{2 高温強度}

$\mathrm{Si}_{3} \mathrm{~N}_{4}$ セラミックスの高温での強度低下の原因は粒界ガ ラス相の軟化による粒界すべりやスロークラックグロウス であることが知られている。本系では， $\mathrm{SiC}$ 粒子は粒界 相, $\mathrm{Si}_{3} \mathrm{~N}_{4}$ 粒内及び $\mathrm{Si}_{3} \mathrm{~N}_{4}-\mathrm{Si}_{3} \mathrm{~N}_{4}$ 二粒子界面に分散してい る. $\mathrm{Si}_{3} \mathrm{~N}_{4}$ 粒子同士は二粒子界面に位置する $\mathrm{SiC}$ 粒子を介 して強固につながれているため, 高温雾囲気下での粒界す べりが抑制される．また，図 7 に示した各構成相量の定 量結果から，炭素蒸着粉末を焼結させ $\mathrm{SiC}$ 相が生成する 々粒界相量は減少し，かつ，粒界結晶相が生成しやすくな る.したがって, 炭素蒸着粉末から焼結体を作製すると高 温強度の劣化の原因となる粒界ガラス相量を減じるととも に $\mathrm{SiC}$ 粒子が $\mathrm{Si}_{3} \mathrm{~N}_{4}-\mathrm{Si}_{3} \mathrm{~N}_{4}$ 二粒子界面に析出し，粒界すべ りやスロークラックグロウスの抵抗となるため高温強度が 向上したと考えられる.

\section{5. 結 論}

$\mathrm{Si}_{3} \mathrm{~N}_{4}$ 粉末に炭素蒸着し in-situ 反応を利用して $\mathrm{Si}_{3} \mathrm{~N}_{4} /$ $\mathrm{SiC}$ ナノ複合体を作製し, 高温強度と焼結体の構成相量の 関係を検討し，以下の結論を得た。

（1） 高温強度は室温強度と同様に炭素蒸着粉末を原料 粉末に用いることで改善された。

(2) 生成した $\mathrm{SiC}$ 粒子は $\mathrm{Si}_{3} \mathrm{~N}_{4}$ 粒界ガラス相, $\mathrm{Si}_{3} \mathrm{~N}_{4}-$ $\mathrm{Si}_{3} \mathrm{~N}_{4}$ 二粒子界面及び $\mathrm{Si}_{3} \mathrm{~N}_{4}$ 粒内に分散している.

（3）粒界ガラス相中に生成した $\mathrm{SiC}$ 粒中には $10 \mathrm{~nm}$ 以 下の微粒子が認められ, 従来報告されているナノ複合体中 で最も微細な粒子を分散させることに成功した，

（4）低温比熱測定結果から in-situ 反応で生成した SiC 相量が同定できた。 また，粒界ガラス相と結晶相の総和は in-situ 反応により $\mathrm{SiC}$ が生成するため減少した.

（5）炭素蒸着粉末から焼結体を作製するとin-situ 反応 により液相中の $\mathrm{SiO}_{2}$ 成分が減少し, 粒界相はガラスとし て存在するよりも結晶相として存在しやすくなることが分 かった。

（6）粒界ガラス相量が減少するとともに，析出した $\mathrm{SiC}$ 粒子が粒界すべりやスロークラックグロウスに対する 抵抗となり高温強度が向上することが分かった。

（日本セラミックス協会1994年年会で発表）

謝辞 本研究を進めるに当たり, 防衛大学校材料物性工学 教室・菅沼克昭助教授にホットプレス装置の使用の便宜を図って 頂きました.ここに深く感謝致します。

\section{文献}

1) F. F. Lange, J. Am. Ceram. Soc., 56, 508-22 (1973).

2) C. Greskovich and J. A. Plam, J. Am. Ceram. Soc., 63, 59799 (1980).

3) S. T. Buljan, J. G. Baldoni and M. L. Huckabee, Am. Ceram. Soc. Bull., 66, 347-52 (1987).

4) Y. Akimune, T. Ogasawara and N. Hirosaki, J. Ceram. Soc. Japan, 100, 463-67 (1992).

5) K. Niihara, Seramikkusu Ronbunshi, 99, 974-82 (1991).

6）渡利広司, 石㠃幸三, 河本 充, セラミックス論文誌, 96, 760-67 (1988).

7）柳井知宏, 石㟝幸三, J. Ceram. Soc. Japan, 101, 764-68 (1993).

8) T. Hamasaki and K. Ishizaki, J. Am. Ceram. Soc., 77, 110103 (1994).

9）渡利広司，関 喜幸，石嵭幸三，セラミックス論文誌， 97， 174-81 (1989).

10) I. Tanaka, H. J. Kleebe, M. K. Cinibulk, J. Bruley, D. R. Clarke and M. Rühle, J. Am. Ceram. Soc., 77, 911-14 (1994).

11) A. Makishima, Y. Tamura and T. Sakaino, J. Am. Ceram. Soc., 61, 247-49 (1978).

12）濱崎豊弘, 石㠃幸三, 奥本良博, 日本セラミックス協会年 会講演予稿集 (1995) p. 618. 